\title{
Analysis of natural radionuclide concentrations in selected building materials available on the domestic market
}

\author{
Aneta Łukaszek-Chmielewska ${ }^{1}$, Martin Girard ${ }^{1}$, Karol Wojtkowski ${ }^{2,}{ }^{*}$, Krzysztof Isajenko ${ }^{2}$, \\ and Barbara Piotrowska ${ }^{2}$ \\ ${ }^{1}$ The Main School of Fire Service, Faculty of Fire Safety Engineering, 52/54 Słowackiego St., 01629 \\ Warsaw, Poland \\ ${ }^{2}$ Central Laboratory for Radiological Protection, 7 Konwaliowa St., 03-194 Warsaw, Poland
}

\begin{abstract}
This article presents the results of natural radioactivity research for selected building materials such as: ceramic blocks, cellular concrete, solid bricks, ceramic roof tiles, cement, mortars, plaster and adhesives available on the domestic market. In Poland, the possibility of using various raw materials and ready-made construction materials depends on the values of activity coefficients $f_{1}$ and $f_{2}$. The activity coefficient $f_{1}$ determines the content of natural isotopes in the examined material, as an indicator of the whole body exposure to gamma radiation. The activity coefficient $\mathrm{f}_{2}$ determines the content of radium ${ }^{226} \mathrm{Ra}$ in the examined material, as an indicator of the epithelial lung exposure to the alpha radiation emitted through radon decay products, taken together with the air by the human respiratory system. Activity coefficients are described by natural potassium ${ }_{40} \mathrm{~K}$, radium ${ }_{226} \mathrm{Ra}$ and $228 \mathrm{Th}$. The activity concentrations of these radionuclide were determined using MAZAR analyzer with a scintillation detector. The highest concentrations of natural radioactive isotopes were recorded for solid bricks, while plaster has the lowest concentration. Nevertheless, none of the tested samples had activity of both coefficients exceeding the limit values, which means each of the analyzed materials can be safely used in buildings intended for human stays or livestock. Additionally, the work has determined the dose rate and effective annual dose equivalent for the analyzed building materials.
\end{abstract}

\section{Introduction}

Natural ionizing radiation is one of the most important environmental factors defining hygienic and health conditions in buildings intended for permanent human stay. The main sources of this radiation include terrestrial, cosmic and internal radiation [1].

The main source of natural radiation is the natural radioactivity coming from constituents of the Earth's crust. These include radionuclide such as potassium $40 \mathrm{~K}$, uranium ${ }^{238} \mathrm{U}$ and thorium ${ }^{232} \mathrm{Th}$ with half-lives of respectively $1.28 \cdot 10^{9}, 4.47 \cdot 10^{9}$ and $1.40 \cdot 10^{10}$ years [2]. They also occur in rocks and minerals used in construction. Therefore,

\footnotetext{
*Corresponding author: karol_wojtkowski@go2.p1
} 
the radiation value on Earth is not constant everywhere, but depends on the geological structure of the ground and ranges from approximately $0.3 \mathrm{mSv} /$ year to approximately 1.5 $\mathrm{mSv} /$ year (average $0.55 \mathrm{mSv} /$ year) [1]. Increased gamma radiations of about $60-80 \%$ are recorded inside geopathic zones compared to outside them, eg $2.07 \mathrm{mSv} / \mathrm{year}$ inside the zone and $1.65 \mathrm{mSv} /$ year one meter away from it [1]. The highest intensity of ionizing radiation was recorded in the mountains of Brazil and equals approximately $120 \mathrm{mSv} / \mathrm{year}$. This is due to the geological structure of those mountains, namely the presence of monocytic rocks [1].

In the case of cosmic rays, the main source is the Sun. The intensity of cosmic radiations depends on the latitude and also on the altitude above sea level. At sea level it is about $0.31 \mathrm{mSv} /$ year, and the higher the altitude the higher the intensity of radiations, because the layer of the Earth's atmosphere, which protects against ionizing radiations, gets thinner. The average dose of radiation coming from cosmic rays is assumed to be 0.33 $\mathrm{mSv} /$ year [1].

The next component of natural radiations are internal radiations whose main source are radioactive elements present in the air, food and drinking water getting into the body. The total mean value of natural ionizing radiation is about $1.05 \mathrm{mSv} /$ year, and ranges within the limits of $0.6-3.0 \mathrm{mSv} /$ year [1].

\section{Radioactivity of building materials and legal regulations regulating them}

Radiation of building materials results mainly from the presence of natural radioactive elements such as: potassium $\left({ }^{40} \mathrm{~K}\right)$, uranium $\left({ }^{238} \mathrm{U}\right)$, radium $\left({ }^{226} \mathrm{Ra}\right)$ and thorium $\left.\left({ }^{232} \mathrm{Th}\right)\right)$ together with their decomposition products. These isotopes are present in the raw materials used for the production of building materials such as sand, clay, calcium or gypsum. When necessary to perform technological treatments of raw materials or as a result of adding to the materials industrial waste such as light aggregates or sintered granules obtained from clays, ashes, slates or slags, the concentration of natural radioactive isotopes in building materials may increase. It should be realized that all mineral materials contain in their composition practically the same natural radioactive elements as the Earth's crust [3].

Due to the fact that people spend the majority of their lives in buildings (about $80 \%$ ), control of the natural radioactive elements concentrations is essential in all branches of the building materials industry in order to provide adequate protection against ionizing radiation $[3,4]$. Radium $\left({ }^{226} \mathrm{Ra}\right)$ is a particularly dangerous element, whose product of decay radon $\left({ }^{222} \mathrm{Rn}\right)$ is a noble gas which undergoes the alpha disintegration. Radon atoms present in the air inside buildings come mainly from geological substrate (about 74\%). Other sources are construction materials (about 13\%), external atmospheric air (about $10 \%$ ), as well as natural gas and water (about 3\%) [1]. The average concentration of radon in residential buildings is estimated to be $33 \%$ higher than the concentration in the open space outside the buildings [1]. People receive from building materials an additional radiation dose in the range of $0.2-2.0 \mathrm{mSv} /$ year [1]. In order to safely frame hygienic and health conditions in the residential buildings, it is necessary to eliminate construction products containing in their composition excessive amounts of natural radioactive isotopes. National testing methods and criteria for the evaluation of construction products are presented in the ITB Guide 455/2010 [3]. This guide provides a definition of two parameters $f_{1}$ and $f_{2}$, which describe respectively [2-9]:

$\mathrm{f}_{1}$ - whole body exposure to gamma rays emitted by natural radioactive elements such as potassium $\left({ }^{40} \mathrm{~K}\right)$, radium $\left({ }^{226} \mathrm{Ra}\right)$ and thorium $\left({ }^{228} \mathrm{Th}\right)$,

$\mathrm{f}_{2}$ - degree of epithelial lung exposure to the radiation of alpha radon ${ }^{222} \mathrm{Rn}$ and its derivatives. 
Values of coefficients $f_{1}$ and $f_{2}$ are calculated according to equations (1) and (2):

$$
f_{1}=\frac{S_{K}}{3000}+\frac{S_{R a}}{300}+\frac{S_{T h}}{200}
$$

where:

$\mathrm{S}_{\mathrm{K}} \cdot \mathrm{S}_{\mathrm{Ra}} \cdot \mathrm{S}_{\mathrm{Th}}$ - potassium $\left({ }^{40} \mathrm{~K}\right)$, radium $\left({ }^{226} \mathrm{Ra}\right)$ and thorium $\left({ }^{228} \mathrm{Th}\right)$ concentrations expressed in $\mathrm{Bq} / \mathrm{kg}$ ds

$$
f_{2}=S_{R a}
$$

where:

$\mathrm{S}_{\mathrm{Ra}}$ - concentration of radium $\left({ }^{226} \mathrm{Ra}\right)$ in $\mathrm{Bq} / \mathrm{kg}$.

Depending on the value of these two coefficients, the tested material can be used in various types of constructions. Furthermore, the values of $f_{1}$ and $f_{2}$ shall not exceed by more than $20 \%$ the values of:

a) $\mathrm{f}_{1}=1$ and $\mathrm{f}_{2}=200 \mathrm{~Bq} / \mathrm{kg}$ for raw materials and building materials used in buildings intended for human stays or livestock;

b) $\mathrm{f}_{1}=2$ and $\mathrm{f}_{2}=400 \mathrm{~Bq} / \mathrm{kg}$ in the case of industrial waste used in ground-based construction projects erected in built-up areas or intended for development in the local spatial development plan. And also for leveling such areas;

c) $\mathrm{f}_{1}=3.5$ and $\mathrm{f}_{2}=1000 \mathrm{~Bq} / \mathrm{kg}$ for industrial waste used in parts of aboveground construction works and for leveling areas not mentioned in item $b$;

d) $\mathrm{f}_{1}=7$ and $\mathrm{f}_{2}=2000 \mathrm{~Bq} / \mathrm{kg}$ for industrial waste used in parts of underground construction works. Referred to in point $\mathrm{c}$, and in underground structures, including in railway and road tunnels. Excluding industrial waste used in underground mining excavations $[3,7,8]$.

What's more, when using industrial waste for leveling areas referred to in points b) and c) and for the construction of roads for sports and recreational facilities, without changing the required values of $f_{1}$ and $f_{2}$ coefficients the dose absorbed at a height of $1 \mathrm{~m}$ above the surface, road or facilities is lowered to a value not exceeding $0.3 \mu \mathrm{Gy} / \mathrm{h}$ by placing an additional layer of other material $[3,7,8]$.

\section{Sample preparation and measurement methodology}

Samples of the tested materials were crushed and sieved through sieves with a fraction of 2 $\mathrm{mm}$. During screening, they were compacted using a vibrator. In order to obtain a constant mass, the samples were dried at $105^{\circ} \mathrm{C}$, and then placed in previously prepared $1.5 \mathrm{dm}^{3}$ Marinella vessels to obtain the same geometry of measurement. The containers were filled in such a way that the test material was located $5 \mathrm{~mm}$ before its upper edge. Then the mass of each sample was measured. The concentration of radon $\left({ }^{222} \mathrm{Rn}\right)$ was determined based on the activity of radium derivatives $\left({ }^{226} \mathrm{Ra}\right)$ and for this purpose it was necessary to ensure th tightness of Marinella containers to avoid loss of radon's concentration, which is a volatile decay product of radium $\left({ }^{226} \mathrm{Ra}\right)$. That's also the reason why the measurements were carried out only once the equilibrium between ${ }^{226} \mathrm{Ra}$ and ${ }^{214} \mathrm{Bi}$ and between ${ }^{228} \mathrm{Th}$ and ${ }^{208} \mathrm{Tl}$ were achieved after approximately 4 weeks. Measurements were done three times for each sample with the same geometry and the obtained results are the arithmetical mean values of the three measurements $[3,7]$.

The research on building materials was carried out using a MAZAR type analyzer combined with a $\mathrm{NaJ}$ (Tl) scintillation detector. It is an analyzer operating in three measuring ranges, which allow the determination of activity coefficients $f_{1}$ and $f_{2}$ as well as 
the radioactivity concentrations of the following radioisotopes: ${ }^{40} \mathrm{~K} .{ }^{226} \mathrm{Ra}$ and ${ }^{228} \mathrm{Th}$. The measuring windows of the analyzers are contained in the following energy ranges $[3,7]$ :

a) potassium $\left({ }^{40} \mathrm{~K}\right)$ window - energy range $1.26 \mathrm{MeV}-1.65 \mathrm{MeV}$,

b) radium $\left({ }^{226} \mathrm{Ra}\right)$ window - energy range $1.65 \mathrm{MeV}-2.30 \mathrm{MeV}$,

c) thorium (228Th) window - energy range $2.30 \mathrm{MeV}-2.85 \mathrm{MeV}$.

Calibration of the detector's performance was based on measurements from three volume calibration standards: ${ }^{40} \mathrm{~K} .{ }^{226} \mathrm{Ra}$ and ${ }^{228} \mathrm{Th}$, as well as the matrix pattern measurement (as background measurement). The geometry of the reference sources were Marinella containers with a capacity of $1.5 \mathrm{dm}^{3}$. The density of reference sources is 1.6 $\mathrm{g} / \mathrm{cm}^{3}$, while the density of measured construction samples ranges from 0.6 to $2.0 \mathrm{~g} / \mathrm{cm}^{3}$. In order to minimize the external background, the detector was placed in a lead protective case with a wall thickness of $50 \mathrm{~mm}$.

Table 1 presents the average values of concentrations of natural radioactive isotopes and calculated values of activity coefficients $f_{1}$ and $f_{2}$ for the analyzed building materials.

Table 1. Concentrations of natural radionuclides and values of activity coefficients $f_{1}$ and $f_{2}$ for the tested building materials.

\begin{tabular}{|c|c|c|c|c|c|}
\hline Sample & $\begin{array}{c}\text { Concentration } \\
\text { of potassium } \\
\mathbf{4 0} \mathbf{K} \\
{[\mathbf{B q} / \mathbf{k g}]}\end{array}$ & $\begin{array}{c}\text { Concentration } \\
\text { of radon } \\
\mathbf{2 2 6} \mathbf{R a} \\
{[\mathbf{B q} / \mathbf{k g}]}\end{array}$ & $\begin{array}{c}\text { Concentration } \\
\text { of thorium } \\
\mathbf{2 2 8} \mathbf{T h} \\
{[\mathbf{B q} / \mathbf{k g}]}\end{array}$ & $\begin{array}{c}\text { Activity } \\
\text { coefficient } \\
\mathbf{f} \mathbf{1} \\
{[\mathbf{B q} / \mathbf{k g}]}\end{array}$ & $\begin{array}{c}\text { Activity } \\
\text { coefficient } \\
\mathbf{f} \mathbf{2} \\
{[\mathbf{B q} / \mathbf{k g}]}\end{array}$ \\
\hline $\begin{array}{c}\text { Ceramic } \\
\text { block 1 }\end{array}$ & $662.86 \pm 74.95$ & $39.63 \pm 10.70$ & $37.93 \pm 5.66$ & $0.53 \pm 0.05$ & $39.63 \pm 10.70$ \\
\hline $\begin{array}{c}\text { Ceramic } \\
\text { block 2 }\end{array}$ & $680.83 \pm 72.79$ & $40.98 \pm 10.17$ & $39.10 \pm 5.44$ & $0.55 \pm 0.05$ & $40.98 \pm 10.17$ \\
\hline $\begin{array}{c}\text { Cellular } \\
\text { concrete }\end{array}$ & $185.98 \pm 44.19$ & $7.17 \pm 1.43$ & $9.28 \pm 3.62$ & $0.13 \pm 0.04$ & $7.17 \pm 1.43$ \\
\hline Solid brick & $914.03 \pm 90.19$ & $40.29 \pm 11.40$ & $45.35 \pm 6.32$ & $0.66 \pm 0.06$ & $40.29 \pm 11.40$ \\
\hline $\begin{array}{c}\text { Ceramic } \\
\text { roof tile }\end{array}$ & $732.57 \pm 68.52$ & $35.34 \pm 9.11$ & $47.70 \pm 5.34$ & $0.59 \pm 0.05$ & $35.34 \pm 9.11$ \\
\hline Mortar & $111.09 \pm 25.80$ & $4.34 \pm 0.26$ & $2.82 \pm 0.93$ & $0.06 \pm 0.01$ & $4.34 \pm 0.26$ \\
\hline $\begin{array}{c}\text { Elastic } \\
\text { sealing } \\
\text { mortar }\end{array}$ & $14.32 \pm 2.49$ & $6.89 \pm 0.69$ & $1.62 \pm 0.45$ & $0.03 \pm 0.01$ & $6.89 \pm 1.69$ \\
\hline $\begin{array}{c}\text { Cement } \\
\text { flooring } \\
\text { mortar }\end{array}$ & $203.75 \pm 33.88$ & $24.36 \pm 2.04$ & $15.56 \pm 2.85$ & $0.22 \pm 0.03$ & $24.36 \pm 2.04$ \\
\hline Cement & $200.18 \pm 37.83$ & $26.83 \pm 3.98$ & $15.89 \pm 3.22$ & $0.23 \pm 0.03$ & $26.83 \pm 2.98$ \\
\hline Plaster & $1.58 \pm 0.22$ & $6.90 \pm 0.16$ & $1.41 \pm 0.20$ & $0.03 \pm 0.01$ & $6.90 \pm 1.16$ \\
\hline $\begin{array}{c}\text { Tile } \\
\text { adhesive }\end{array}$ & $125.96 \pm 30.89$ & $20.16 \pm 6.03$ & $14.13 \pm 2.88$ & $0.17 \pm 0.01$ & $20.16 \pm 3.03$ \\
\hline
\end{tabular}

Additionally, for each of the studied materials, the radiation dose rate and the annual effective dose received by the building materials were determined. The dose rate is defined in the literature [4] as the ratio of dose to time, and thus describes the rate of irradiation in the room. Based on the knowledge of the concentrations of natural radioactive isotopes, 
namely potassium $\left({ }^{40} \mathrm{~K}\right)$, radium $\left({ }^{226} \mathrm{Ra}\right)$ and thorium $\left({ }^{228} \mathrm{Th}\right)$, the dose rate value is calculated according to the formula (3):

$$
D=0.12 \cdot S_{R a}+0.14 S_{T h}+0.0098 \cdot S_{K}
$$

where:

$\mathrm{S}_{\mathrm{Ra}}, \mathrm{S}_{\mathrm{Th}}, \mathrm{S}_{\mathrm{K}}$ - radium, thorium and potassium concentrations in $\mathrm{Bq} / \mathrm{kg}$.

On the basis of the determined dose rate $D$, the effective dose of radiation at external and internal exposure can be calculated $[4,10]$. The effective dose $D_{E}$ (mSv/year) received annually by the population from building materials contained in the floor, walls and ceiling of the building is calculated according to the equation (4):

$$
D_{E}=0.7 \cdot 7000 h \cdot D
$$

where:

$0.7[\mathrm{~Sv} / \mathrm{h}]$ - conversion factor of the absorbed dose expressed in Gy into the effective dose $\mathrm{Sv}$,

$7000 \mathrm{~h}$ - annual exposure time.

Calculated on the basis of equations (3) and (4) values of dose rate and effective dose for tested materials are presented in Table 2 .

Table 2. Dose rate and annual effective dose in the tested building materials.

\begin{tabular}{|l|r|c|}
\hline \multicolumn{1}{|c|}{ Sample } & $D_{\text {[nGy/h] }}$ & DE $[\mathbf{m S v}]$ \\
\hline Ceramic block 1 & 16.43 & 0.081 \\
\hline Ceramic block 2 & 16.93 & 0.083 \\
\hline Cellular concrete & 3.95 & 0.019 \\
\hline Solid brick & 19.96 & 0.098 \\
\hline Ceramic roof tile & 17.95 & 0.088 \\
\hline Mortar & 1.98 & 0.010 \\
\hline Elastic sealing mortar & 1.19 & 0.006 \\
\hline Cement flooring mortar & 7.06 & 0.035 \\
\hline Cement & 7.37 & 0.036 \\
\hline Plaster & 1.04 & 0.005 \\
\hline Tile adhesive & 5.61 & 0.027 \\
\hline
\end{tabular}

\section{Analysis of measurement results and conclusions}

Looking at the obtained results placed in Table 1, it can be noticed that all tested materials had in their composition natural radioactive elements such as potassium $\left({ }^{40} \mathrm{~K}\right)$, radium $\left({ }^{226} \mathrm{Ra}\right)$ and thorium $\left({ }^{228} \mathrm{Th}\right)$. The predominant radioactive isotope in the studied building materials was potassium $\left({ }^{40} \mathrm{~K}\right)$. This is due to its ubiquity in the earth's crust. Its concentration ranged from $1.58 \mathrm{~Bq} / \mathrm{kg}$ to $914.03 \mathrm{~Bq} / \mathrm{kg}$. Analyzing the results obtained for potassium $\left({ }^{40} \mathrm{~K}\right)$ concentrations, it can be concluded that the highest concentration of this isotope was recorded for solid bricks $(914.03 \mathrm{~Bq} / \mathrm{kg}$ ) and ceramic materials (ceramic roof tiles and ceramic blocks 1 and 2). However, the lowest potassium concentration was obtained for plaster $(1.58 \mathrm{~Bq} / \mathrm{kg})$ and for elastic sealing mortar $(14.32 \mathrm{~Bq} / \mathrm{kg})$. 
Another equally important natural radioactive element is radium $\left({ }^{226} \mathrm{Ra}\right)$, which is the radon mother isotope. It is necessary to be aware that radon is the main source of exposure to natural radiation, as presented in the Annual Report by the President of the National Atomic Energy Agency [11]. The total natural radiation exposure for the inhabitants of Poland from natural sources is about $2.4 \mathrm{mSv} /$ year, of which $1.2 \mathrm{mSv}$ comes from radon and its short-lived derivatives. The concentration of this element is important because it determines the coefficient $\mathrm{f}_{2}$, which cannot exceed the limit of $240 \mathrm{~Bq} / \mathrm{kg}$ so that the material can be used in rooms intended for human and animal stays. The concentration of radium $\left({ }^{226} \mathrm{Ra}\right)$ in the tested materials ranged from $4.34 \mathrm{~Bq} / \mathrm{kg}$ to $40.98 \mathrm{~Bq} / \mathrm{kg}$. As for the potassium isotope, the highest concentration of radium was recorded for ceramic blocks and solid bricks. The lowest concentration of this isotope was obtained respectively for mortar $(4.34 \mathrm{~Bq} / \mathrm{kg})$, elastic sealing mortar $(6.89 \mathrm{~Bq} / \mathrm{kg})$, plaster $(6.90 \mathrm{~Bq} / \mathrm{kg})$ and cellular concrete (7.17 Bq/kg).

In the case of the thorium isotope $\left({ }^{228} \mathrm{Th}\right)$, the highest concentration was recorded for ceramic roof tiles $(47.70 \mathrm{~Bq} / \mathrm{kg})$, followed by solid brick $(45.35 \mathrm{~Bq} / \mathrm{kg})$ and ceramic blocks. The lowest concentration of thorium was found in plaster $(1.41 \mathrm{~Bq} / \mathrm{kg})$ and elastic sealing $\operatorname{mortar}(1.62 \mathrm{~Bq} / \mathrm{kg})$.

In Poland, the Central Radiological Protection Laboratory (CLOR) is investigating radioactivity in building materials. In the years 1980 - 2013, CLOR tested 2731 brick samples, 1560 cement samples, 49 ceramic roof tiles, 4649 ceramic samples, 4 cement binders, etc. The concentrations of natural radioactive isotopes, i.e. radium, thorium and potassium, were determined in these samples. and the activity coefficient $f_{1}$ of the tested materials was determined. The results are presented in Table 3 [3].

Table 3. Concentrations of natural radionuclide and the value of activity coefficient $f_{1}$ for selected construction materials examined in the years 1980 - 2013 (average values in brackets) [3].

\begin{tabular}{|c|c|c|c|c|c|}
\hline Sample & $\begin{array}{c}\text { Number of } \\
\text { samples }\end{array}$ & $\begin{array}{c}\text { Concentration of } \\
\text { potassium } \\
\mathbf{4 0} \mathbf{K} \\
{[\mathbf{B q} / \mathbf{k g}]}\end{array}$ & $\begin{array}{c}\text { Concentration } \\
\mathbf{0} \mathbf{~ r a d o n} \\
\mathbf{2 2 6} \mathbf{R a} \\
{[\mathbf{B q} / \mathbf{k g}]}\end{array}$ & $\begin{array}{c}\text { Concentration of } \\
\text { thorium } \\
\mathbf{2 2 8} \mathbf{T h} \\
{[\mathbf{B q} / \mathbf{k g}]}\end{array}$ & $\begin{array}{c}\text { Activity } \\
\mathbf{c o e f f i c i e n t} \\
\mathbf{f} \mathbf{1} \\
{[\mathbf{B q} / \mathbf{k g}]}\end{array}$ \\
\hline Bricks & 2731 & $\begin{array}{c}66-1330 \\
(546.41)\end{array}$ & $\begin{array}{c}0.1-127.8 \\
(35.60)\end{array}$ & $\begin{array}{c}0-130 \\
(31.75)\end{array}$ & $\begin{array}{c}0.05-1.17 \\
(0.46)\end{array}$ \\
\hline Cement & 1560 & $\begin{array}{c}6-7149.2 \\
(405.52)\end{array}$ & $\begin{array}{c}0-119 \\
(44.91)\end{array}$ & $6.6-78.3(26.03)$ & $\begin{array}{c}0.08-2.52 \\
(0.42)\end{array}$ \\
\hline $\begin{array}{l}\text { Ceramic } \\
\text { roof tile }\end{array}$ & 49 & $\begin{array}{c}332-887 \\
(517.37)\end{array}$ & $\begin{array}{c}26-60 \\
(42.59)\end{array}$ & $\begin{array}{c}31-57 \\
(43.47)\end{array}$ & $\begin{array}{c}0.39-0.69 \\
(0.53)\end{array}$ \\
\hline Plaster & 4 & $89-430(299.03)$ & $\begin{array}{c}31.8-181.9 \\
(83.75)\end{array}$ & $\begin{array}{c}10.2-93.2 \\
(51.23)\end{array}$ & $\begin{array}{c}0.19-1.20 \\
(0.64)\end{array}$ \\
\hline Ceramics & 4649 & $\begin{array}{c}55-1368 \\
(684.41)\end{array}$ & $\begin{array}{c}1-214 \\
(51.12)\end{array}$ & $1-214(49.25)$ & $\begin{array}{c}0.08-1.74 \\
(0.64)\end{array}$ \\
\hline
\end{tabular}

For the ceramic materials tested, i.e. ceramic blocks and ceramic roof tiles, average potassium, radium and thorium concentrations can be found in the following ranges:

- potassium $662.86-732.57 \mathrm{~Bq} / \mathrm{kg}$,

- $\quad$ radium $35.34-40.98 \mathrm{~Bq} / \mathrm{kg}$,

- thorium $37.93-47.70 \mathrm{~Bq} / \mathrm{kg}[3]$.

Thus, it can be stated that the determined concentrations of natural radionuclide are within the concentration ranges determined by CLOR and in the case of radium and thorium, they reach the lower values.

However, for solid bricks, the determined concentrations of all natural isotopes are higher than the average values obtained by CLOR. 
For cement and cement binder (cement flooring mortar), the results obtained show a lower concentrations of potassium, thorium and radium than the average values obtained by CLOR.

Considering the values of the $f_{1}$ activity coefficient obtained during the measurements (Tab.2.), one can see that the safest materials concerning the exposure of the whole human body to gamma radiation emitted by natural radionuclide such as potassium $\left({ }^{40} \mathrm{~K}\right)$, radium $\left({ }^{226} \mathrm{Ra}\right)$ and thorium $\left({ }^{228} \mathrm{Th}\right)$ were elastic sealing mortar and plaster. Their activity coefficients $f_{1}$ reached $0.03 \mathrm{~Bq} / \mathrm{kg}$. This is due to the fact that in both materials the potassium and thorium concentrations were low. The highest value of this parameter was obtained for solid brick $(0.66 \mathrm{~Bq} / \mathrm{kg})$ and ceramic materials, ie ceramic roof tiles and solid bricks. The limit value of the activity coefficient $f_{1}=1.24 \mathrm{~Bq} / \mathrm{kg}$ has not been exceeded in any of the materials examined.

In the case of the activity coefficient $\mathrm{f}_{2}$, which determines the content of radium $\left({ }^{226} \mathrm{Ra}\right)$ in the studied sample and the associated exposure to radon $\left({ }^{222} \mathrm{Rn}\right)$ and its degradation products, most of all alpha radioactive polonium $\left({ }^{218} \mathrm{Po}\right.$ and $\left.{ }^{214} \mathrm{Po}\right)$, it can be noticed that its range for all the tested construction materials is wide and within the limits of $4.34-40.98$ $\mathrm{Bq} / \mathrm{kg}$. Nevertheless, in this case too the limit value of $240 \mathrm{~Bq} / \mathrm{kg}$ for the activity coefficient $\mathrm{f}_{2}$ was not exceeded for any of the tested materials.

Therefore, each of the samples tested is safe regarding ionizing radiation and can be used in buildings intended for human stays or livestock.

Considering the radiation dose rate obtained for the tested construction materials, it can be seen that it ranges from $1.04-19.96 \mathrm{nGy} / \mathrm{h}$. The lowest dose rate was obtained for plaster $(1.04 \mathrm{nGy} / \mathrm{h})$, and the highest one for solid brick $(19.96 \mathrm{nGy} / \mathrm{h})$. Furthermore, none of the analyzed samples exceeds the effective limit value for the general population equal to $1 \mathrm{mSv} /$ year.

Summing up all the obtained results, it can be stated that the selected building materials meet the requirements set out in the Regulation of the Council of Ministers of January 2, 2007 (Journal of Laws No. 4 item 29) and can be used both in buildings intended for human stays or livestock [8].

\section{References}

1. A. Kuliczkowski, R. Pluta, D. Zwierzchowski, Radioaktywność w środowisku człowieka. Monitoring środowiska regionu świętokrzyskiego, Kieleckie Towarzystwo Naukowe, 1, 47-50 (1993)

2. M. Dohojda, J.A. Rubin, Materiaty Ceramiczne 61, 155-58 (2009)

3. B. Piotrowska, K.Isajenko, M. Fujak, J. Szymczyk, M. Krajewska, PTJ vol. 58, Z.4 (2015)

4. M. Długosz, H. Bem, Ceramic Materials, 60, 4, 163 - 167 (2008)

5. L. Brunarski, M.Dohojda, Prace Instytutu Techniki Budowlanej - Kwartalnik nr 1, 109 (1999)

6. G. Zapotoczna-Sytek K. Mamont-Cieśla, T. Rybarczyk, Przegląd Budowlany 7-8, 3942 (2012)

7. B. Piotrowska, M. Fujak, K. Isajenko, S. Krawczyńska, BiTP vol. 44 Issue 4 pp. 151158 (2016)

8. Rozporządzenie Rady Ministrów z dn. 2 stycznia 2007 roku (Dz. U. Nr 4, poz. 29) (The Ordinance of the Council of Ministers of 2 January 2007, (Journal of Laws No 4 pos. 29)

9. A. Żak, K. Isajenko., B. Piotrowska , M. Kuczbajska , A. Ząbek, T. Szczygielski, Nukleonika, 55(3), 387-391 (2008). 
10. C. Papastefanou, S. Stoulos, M. Manolopoulou, Journal of Radioanalytical and Nuclear Chemistry, 266, 367-372 (2005)

11. Raport roczny Prezesa Państwowej Agencji Atomistyki za 2017 r. 